\title{
Green protocol for the synthesis of 1,8-dioxo-decahydroacridines by Hantzsch condensation using citric acid as organocatalyst
}

\author{
Monika Patil ${ }^{1}$, Shrikrishna Karhale ${ }^{1}$, Ananada Kudale ${ }^{1}$, Arjun Kumbhar ${ }^{2}$, \\ Sagar More ${ }^{2}$ and Vasant Helavi ${ }^{1, *}$ \\ ${ }^{1}$ Department of Chemistry, Rajaram College, Kolhapur 416 004, India \\ ${ }^{2}$ Department of Chemistry, P. D. V. P. College, Tasgaon 416 312, India
}

\begin{abstract}
Herein we describe a clean and sustainable, one-pot, multi-component protocol for the synthesis of 1,8dioxo-decahydroacridines by Hantzsch condensation of cyclic 1,3-dicarbonyl compound and $\mathrm{NH}_{4} \mathrm{OAc}$ with diverse aryl aldehydes using citric acid as an inexpensive green additive in ecological safe solvent. Utilization of cheaper and safer catalyst, cleaner reaction profile, straightforward work-up procedure and good to excellent yields of the desired product are the noteworthy aspects of this method.
\end{abstract}

Keywords: Acridines, citric acid, organocatalysts, green protocol, multi-component reactions.

OUR environment needs to be protected from the growing amounts of waste and toxic by-products that sequentially lead to chemical pollution. Therefore, synthetic chemists are interested to develop relatively safer technologies which play a vital role in green chemistry. Establishing newer chemical transformations should satisfy the green principles such as non-toxic, non-flammability, ecofriendly medium, and separation as well as recycling of the catalysts. Since the last decade, efforts have been made towards the design and synthesis of an environment-friendly method with respect to reagents, catalysts and solvents that could be easily biodegradable ${ }^{1,2}$. Multicomponent reaction (MCR) strategies have been widely used in the convergent synthesis of complex organic entities. The MCRs uses simple and easily available starting materials and provide high atom economy and selectivity. It is one of the important synthetic tools available to achieve both economic and environment-friendly goals. Therefore, the synthesis of heterocyclic compounds using significant bioactivities with MCR support is an important pursuit in organic synthesis.

Synthesis of acridines is a growing area of interest due to polyfunctionalized groups with a wide range of biolo-

*For correspondence. (e-mail: vbhelavi@gmail.com) gical activities ${ }^{3}$. Among them, 1,8-dioxo-decahydroacridines is an important class of aza-heterocycles in which a phenyl-substituted pyridine ring is fused with two cyclohexanone rings. These structures contain 1,4dihydropyridine (1,4-DHP) as a parent core, which acts as fluorescent probes in bioanalytical chemistry ${ }^{4}$ and also used as potential drug candidates for the treatment of cardiovascular diseases. Some of these compounds are used in dye-sensitized solar cells and in the preparation of blue light-emitting devices ${ }^{5,6}$. In addition, 1,8-dioxodecahydroacridines have been widely employed as DNA intercalators, SIRT1 inhibitors, and calcium and potassium channel modulators ${ }^{7,8}$. Several studies have revealed that these heterocycles exhibit numerous medicinal applications which include antitumour, calcium-channel blockers, antileukemic, antifungal, anticancer, anti-atherosclerotic and bronchodilator ${ }^{9-13}$. They are also used as laser dyes, chemosensors and initiators in the photopolymerization process. These derivatives are highly important due to their structural similarities with coenzyme nicotinamide adenine dinucleotide (NADH), which plays an important role in biological systems.

The most common route for the synthesis of 1,8-dioxodecahydroacridines is the condensation of a diverse range of aryl aldehydes, dimedone or cyclic 1,3-dicarbonyl compounds with various nitrogen sources such as ammonium acetate, urea, ammonium hydroxide, ammonium bicarbonate and hydroxylamine ${ }^{14-18}$. A variety of catalysts such as sulphonated polyethylene glycol ( $\left.\mathrm{PEG}-\mathrm{OSO}_{3} \mathrm{H}\right)$, silzic $\left(\mathrm{SiO}_{2}-\mathrm{ZnCl}_{2}\right)$, silica boron-sulphuric acid, proline, $\mathrm{Zn}(\mathrm{OAc})_{2}$, nano nickel cobalt ferrite $\left(\mathrm{Ni}_{0.5} \mathrm{Co}_{0.5} \mathrm{Fe}_{2} \mathrm{O}_{4}\right)$, carbon-based solid acid, Bronsted acidic imidazolium salts, ascorbic acid, acetic acid, tris(pentafluorophenyl) borane/ $\mathrm{B}\left(\mathrm{C}_{6} \mathrm{~F}_{5}\right)_{3}$, silica-supported polyphosphoric acid, ammonium chloride, silica-supported Preyssler nanoparticles have been employed in this reaction ${ }^{19-32}$. However, most of these reported methods have certain drawbacks such as use of toxic and corrosive solvents, expensive reagents, tedious preparation of catalyst, prolonged reaction times, complicated work-up procedure, harsh reaction 


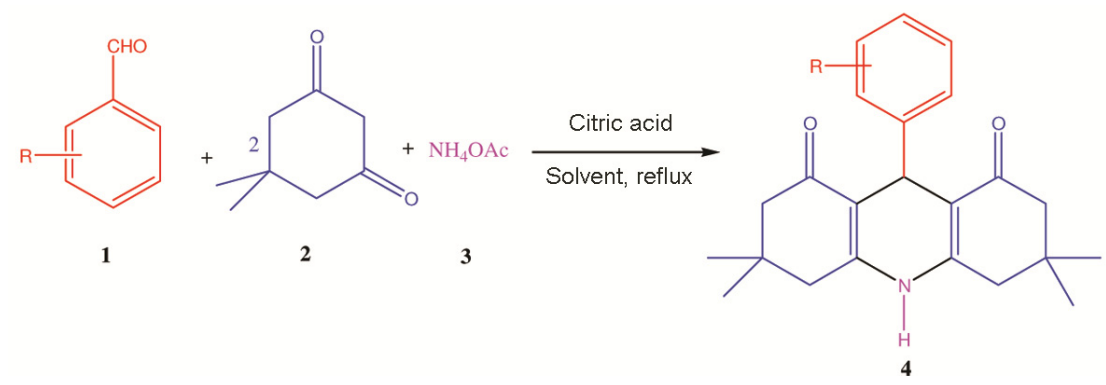

Scheme 1. Citric acid-catalyzed multi-component synthesis of 1,8-dioxo-decahydroacridines.

Table 1. Optimization of solvent for the synthesis of 1,8-dioxodecahydroacridine ${ }^{\mathrm{a}}$

\begin{tabular}{llcc}
\hline Entry & \multicolumn{1}{c}{ Solvent } & Time (min) & Yield (\%) $^{\mathrm{b}}$ \\
\hline 1 & Water & 240 & 70 \\
2 & Ethanol & 150 & 89 \\
3 & Ethanol : water & 200 & 80 \\
4 & Methanol & 300 & 72 \\
5 & Acetonitrile & 360 & 68 \\
6 & Dichloroethane & 400 & 55 \\
7 & Toulene & 390 & 65 \\
\hline
\end{tabular}

${ }^{\mathrm{a}}$ Reaction conditions: Benzaldehyde $(1 \mathrm{mmol})$, dimedone $(2 \mathrm{mmol})$, $\mathrm{NH}_{4} \mathrm{OAc}(1.5 \mathrm{mmol})$ and citric acid monohydrate $(2 \mathrm{mmol})$ in solven $(4 \mathrm{ml})$ at reflux. ${ }^{b}$ Isolated yields.

conditions and low yields of the anticipated product. Therefore, a great demand still exists for the utilization of an efficient, simple and eco-friendly process, especially using cheaply available organocatalysts.

Citric acid is a weak organic acid with the formula $\mathrm{C}_{6} \mathrm{H}_{8} \mathrm{O}_{7}$; it was initially isolated and crystallized from lemon juice in 1784. It has been found as a natural preservative and antioxidant in a variety of citrus fruits like orange, lemon, pineapple, peach and pear. This organic acid is the most widespread intermediate product of metabolism. Furthermore, citric acid is also used for the preparation of salt and forms complexes with many metals such as magnesium, iron, manganese, calcium and copper. Due to its widespread presence, non-toxic nature and chemical stability, it has been used for sequestering in industrial process, as a softener in detergent, as an anticoagulant blood preservative and as a complexing agent in metal treatment. Other industrial and pharmaceutical applications of citric acid include an antioxidant in cosmetics, cleaning and buffering. Despite its huge industrial and pharmaceutical importance, only a few reports exemplify its catalytic application in organic synthesis.

In continuation of our research on the development of green and sustainable methodologies for the synthesis of bioactive heterocyclic scaffolds ${ }^{33-37}$, herein we describe a green protocol for the synthesis of 1,8-dioxo-decahydroacridines from one-pot, MCR of dimedone and $\mathrm{NH}_{4} \mathrm{OAc}$ with a range of aryl aldehydes in the presence of readily available citric acid as organocatalyst in ethanol at reflux.

\section{Results and discussion}

In order to optimize the various reaction conditions, such as effect of solvents and catalyst, the reaction of benzaldehyde $(1 \mathrm{mmol})$, dimedone $(2 \mathrm{mmol})$, and $\mathrm{NH}_{4} \mathrm{OAc}$ $(1.2 \mathrm{mmol})$ was selected as the template in the presence of citric acid $(2 \mathrm{mmol})$ as organocatalyst (Scheme 1$)$.

In a preliminary experiment, the reaction was carried out in various solvents such as water, ethanol, ethanol: water, methanol, acetonitrile, dichloroethane and toluene at reflux; Table 1 shows the results. The best result was obtained in ethanol providing an excellent yield (89\%) of the expected product in $150 \mathrm{~min}$. (Table 1, entry 2). Though the reaction proceeded in water (Table 1, entry 1) ethanol:water $(1: 1)$, methanol, acetonitrile, dichloroethane or toluene, the yield of the desired product was moderate in these solvents with prolonged reaction time (Table 1, entries 3-7).

Next, we optimized the catalyst by varying the amount of citric acid; Table 2 provides the results. The amount of catalyst plays a crucial role in the yield of the desired product. No product was formed without catalyst (Table 2 , entry 1 ). When the amount of citric acid was increased, the yield of the desired product also significantly increased (Table 2, entries 1-3). Maximum yield was obtained in the presence of $2.0 \mathrm{mmol}$ catalyst (Table 2, entries 1-4). Further increase in the amount of citric acid did not have a profound influence on the yield as well as reaction time of the anticipated product (Table 2, entry 5).

After optimization of the reaction conditions, we evaluated the scope and generality of the present protocol by the reaction of a variety of substituted aryl aldehydes, dimedone and $\mathrm{NH}_{4} \mathrm{OAc}$ in the presence of catalyst $(2.0 \mathrm{mmol})$ in ethanol at reflux; Table 3 shows the results. The aromatic aldehydes with varied electronic structure undergo smooth conversion affording the expected 1,8-dioxodecahydroacridines in good to excellent yields. It was observed that the electronic structure of the substituents on aldehyde had little influence on the yield of the anticipated 1,8-dioxo-decahydroacridines. Furthermore, aromatic hetrocyclic aldehyde also showed good conversion with $81 \%$ yield (Table 3 , entry 10 ). However, the reaction of aliphatic aldehyde showed low yield with prolonged reaction time (Table 3 , entry 11). 


\section{RESEARCH ARTICLES}

The recyclability of the catalyst was checked for model reactions; Figure 1 depicts the results. After completion of reaction, the product was recovered by filtration and the filtrate was extensively extracted with chloroform. The catalyst present in the aqueous layer was then dried under vacuum before performing the reusability test. The recovered citric acid could be used in the next reaction cycle. The results indicated that the catalyst could be reused for at least three runs with a modest change in the yield of the product.

Figure 2 shows the plausible mechanism of the formation 1,8-dioxodecahydroacridines. First, citric acid promotes enolization of 1,3-diketone (2), which reacts with aldehyde (1) to form the Knoevengel adduct (5). The adduct (5), undergoes Michael addition with the second molecule of dimedone to yield intermediate (6). The intermediate (6) then reacts with ammonium acetate to yield amine (7) by imine intermediate. The resulting imine (7) undergoes intramolecular cyclization followed by dehydration to yield the desired product (4).

In order to compare the efficiency and advantages of citric acid with reported catalysts, we have tabulated several

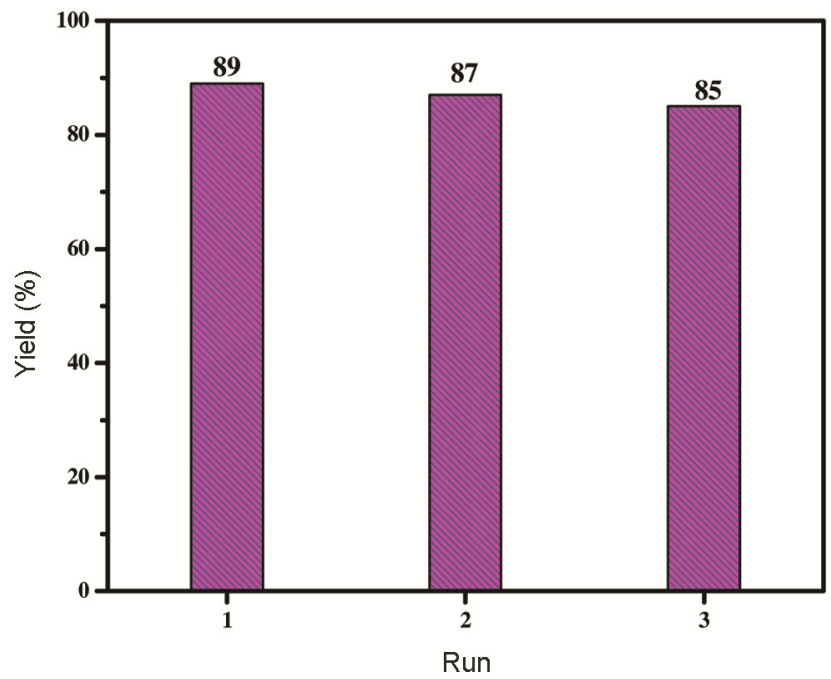

Figure 1. Reusability of citric acid for synthesis of 1,8-dioxodecahydroacridines.

Table 2. Optimization of catalyst for the synthesis of 1,8-dioxodecahydroacridine $^{\mathrm{a}}$

\begin{tabular}{lccc}
\hline Entry & Catalyst (mmol) & Time (min) & Yield (\%) \\
\hline 1 & - & 150 & - \\
2 & 1 & 150 & 68 \\
3 & 1.5 & 150 & 78 \\
4 & 2.0 & 150 & 89 \\
5 & 3.0 & 150 & 89 \\
\hline
\end{tabular}

${ }^{a}$ Reaction conditions: Benzaldehyde $(1 \mathrm{mmol})$, dimedone $(2 \mathrm{mmol})$, $\mathrm{NH}_{4} \mathrm{OAc}(1.5 \mathrm{mmol})$ and citric acid monohydrate $(1-3 \mathrm{mmol})$ in ethanol $(4 \mathrm{ml})$ at reflux. ${ }^{\mathrm{b}}$ Isolated yields. results in the synthesis of 1,8-dioxo-decahydroacridines (Table 4). The table shows that citric acid is effective in terms of yield as well as reaction time compared to the reported catalysts.

\section{Experimental}

All the chemicals were obtained from a local supplier and used without further purification. The melting points were determined by open capillary method and are uncorrected. The FTIR spectra (Bruker ALPHA FTIR spectrometer) and NMR spectra (Bruker $\mathrm{AC} ; 400 \mathrm{MHz}$ for ${ }^{1} \mathrm{H}$ NMR and $75 \mathrm{MHz}$ for ${ }^{13} \mathrm{C}$ NMR spectrometer using TMS as an internal standard) were recorded. The chemical shifts $(\delta)$ are expressed in parts per million.

\section{General procedure for the synthesis of 1,8-dioxo-decahydroacridine derivatives}

A mixture of aromatic aldehyde $(1 \mathrm{mmol})$, dimedone ( $2 \mathrm{mmol}), \mathrm{NH}_{4} \mathrm{OAc}(1.2 \mathrm{mmol})$ and citric acid $(2 \mathrm{mmol})$ was stirred in ethanol $(4 \mathrm{ml})$ at reflux. After completion of the reactions as monitored by thin layer chromatography (TLC), the reaction mixture was allowed to cool at room temperature, poured into ice-cold water $(20 \mathrm{ml})$ and stirred continuously for $10 \mathrm{~min}$. The resultant solid was filtered, washed with cold water and then dried. The crude solid was recrystallized in ethanol and characterized by spectroscopic techniques.

\section{Spectral data}

3,3,6,6-Tetramethyl-9-(phenyl)-1,8-dioxo-decahydroacridine (Table 3, entry 1): Yield 89\%, m.p.: $193-195^{\circ} \mathrm{C}$, $\left(192-194^{\circ} \mathrm{C}\right)^{27} ;{ }^{1} \mathrm{H}$ NMR $\left(400 \mathrm{MHz}, \mathrm{CDCl}_{3}\right) \delta$ (ppm): $7.45(\mathrm{~s}, 1 \mathrm{H}, \mathrm{NH}), 7.65-7.10(\mathrm{~m}, 5 \mathrm{H}, \mathrm{Ar}-\mathrm{H}), 5.15(\mathrm{~s}, 1 \mathrm{H}$, $\mathrm{CH}), 2.42-2.17\left(\mathrm{~m}, 8 \mathrm{H}, \mathrm{CH}_{2}\right), 1.12\left(\mathrm{~s}, 6 \mathrm{H}, \mathrm{CH}_{3}\right), 0.98$ (s, $\left.6 \mathrm{H}, \mathrm{CH}_{3}\right) ;{ }^{13} \mathrm{C}$ NMR $\left(75 \mathrm{MHz}, \mathrm{CDCl}_{3}\right) \delta: 193.8,148.3$, 136.4, 126.8, 128.1, 126.8, 114.3, 51.1, 41.3, 34.2, 33.6, 29.9, 27.6; IR (KBr, cm $\left.{ }^{-1}\right): 3275,2959,1631,1368$.

\section{3,3,6,6-tetramethyl-9-(4-chlorophenyl)-1,8-dioxo-deca-} hydroacridine (Table 3, entry 3): Yield 87\%, m.p.: 294$296^{\circ} \mathrm{C},\left(295-297^{\circ} \mathrm{C}\right)^{27} ;{ }^{1} \mathrm{H}$ NMR $\left(400 \mathrm{MHz}, \mathrm{CDCl}_{3}\right) \delta$ (ppm): 7.66 (s, 1H, NH), 7.48 (d, $J=9 \mathrm{~Hz}, 2 \mathrm{H}, \mathrm{Ar}-\mathrm{H})$, 7.38 (d, $J=9 \mathrm{~Hz}, 2 \mathrm{H}, \mathrm{Ar}-\mathrm{H}), 5.16(\mathrm{~s}, 1 \mathrm{H}, \mathrm{CH}), 2.30-2.13$ $\left(\mathrm{m}, 8 \mathrm{H}, \mathrm{CH}_{2}\right), 1.17\left(\mathrm{~s}, 6 \mathrm{H}, \mathrm{CH}_{3}\right), 0.95\left(\mathrm{~s}, 6 \mathrm{H}, \mathrm{CH}_{3}\right) ;{ }^{13} \mathrm{C}$ NMR $\left(75 \mathrm{MHz}, \mathrm{CDCl}_{3}\right) \delta: 196.1,150.1,144.9,132.0$, 130.1, 127.9, 113.2, 51.5, 41.1, 34.4, 33.6, 30.5, 26.8; IR $\left(\mathrm{KBr}, \mathrm{cm}^{-1}\right): 3436,2954,1647,1612,1365$.

3,3,6,6-Tetramethyl-9-(4-cynophenyl)-1, 8-dioxo-decahydroacridine (Table 3, entry 5): Yield 74\%, m.p.: $<300^{\circ} \mathrm{C}, \quad\left(<300^{\circ} \mathrm{C}\right)^{35} ;{ }^{1} \mathrm{H} \mathrm{NMR} \quad\left(400 \mathrm{MHz}, \mathrm{CDCl}_{3}\right) \quad \delta$ (ppm): 7.52 (d, $J=8.3 \mathrm{~Hz}, 2 \mathrm{H}, \mathrm{Ar}-\mathrm{H}), 7.46$ (d, $J=8.3 \mathrm{~Hz}$, 


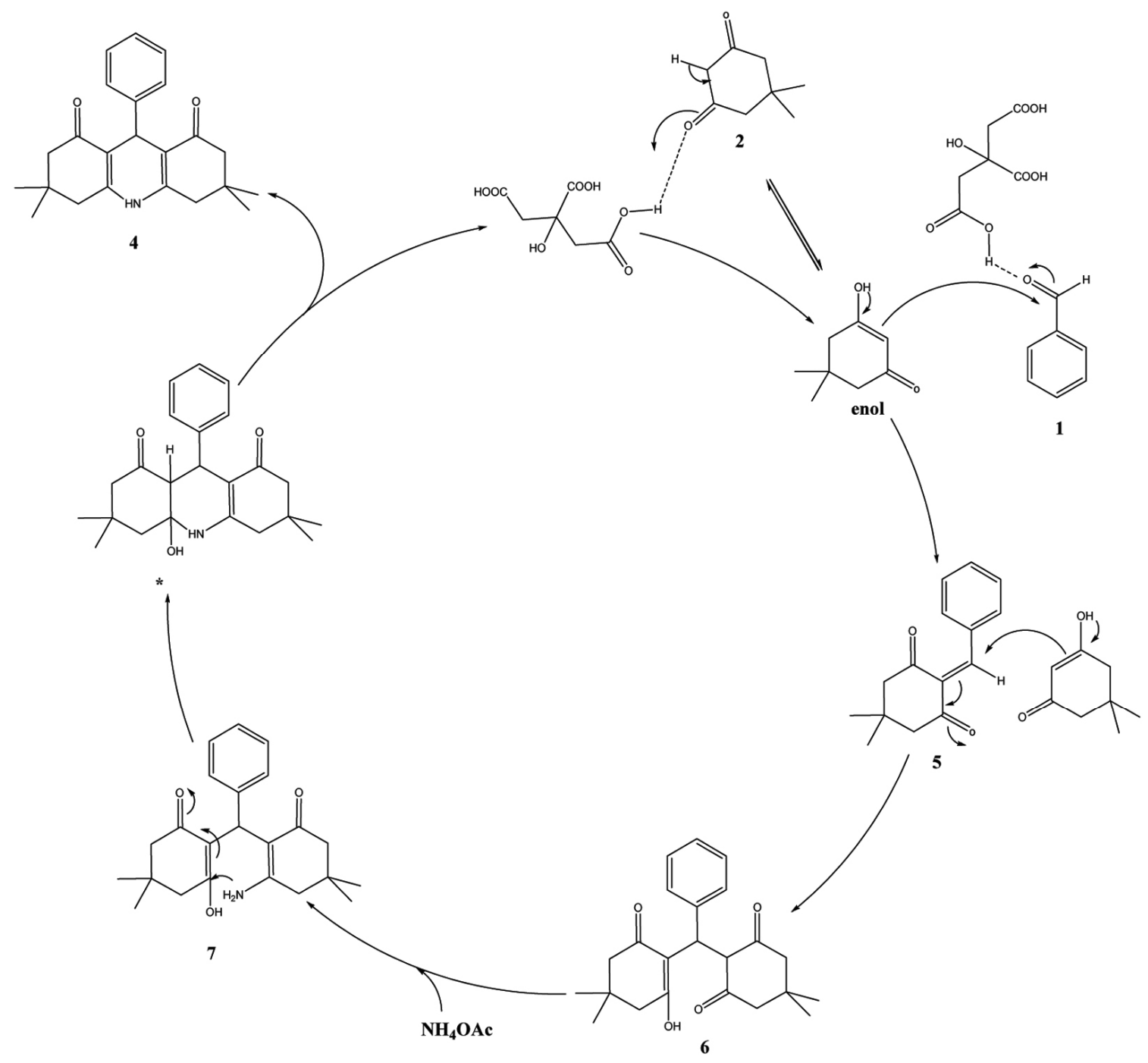

Figure 2. Proposed reaction mechanism for the synthesis of 1,8-dioxo-decahydroacridines.

$2 \mathrm{H}, \mathrm{Ar}-\mathrm{H}), 5.11(\mathrm{~s}, 1 \mathrm{H}, \mathrm{CH}), 5.91(\mathrm{~s}, 1 \mathrm{H}, \mathrm{NH}), 2.43(\mathrm{~d}$, $J=16.5 \mathrm{~Hz}, 2 \mathrm{H}), 2.26(\mathrm{~d}, J=16.5 \mathrm{~Hz}, 2 \mathrm{H}), 2.28(\mathrm{~d}$, $J=16.5 \mathrm{~Hz}, 2 \mathrm{H}), 2.19(\mathrm{~d}, J=16.5 \mathrm{~Hz}, 2 \mathrm{H}), 1.13(\mathrm{~s}, 6 \mathrm{H}$, $\left.\mathrm{CH}_{3}\right), 0.96\left(\mathrm{~s}, 6 \mathrm{H}, \mathrm{CH}_{3}\right) ;{ }^{13} \mathrm{C} \mathrm{NMR}\left(75 \mathrm{MHz}, \mathrm{CDCl}_{3}\right) \delta$ : $194.8,148.7,146.1,130.2,129.5,120.7,112.9,50.4$, $32.9,32.0,30.5,29.1,26.6)$; IR $\left(\mathrm{KBr}, \mathrm{cm}^{-1}\right): 3321,2955$, $2233,1631,1491$.

3,3,6,6-Tetramethyl-9-(4-methoxyphenyl)-1,8-dioxo-decahydroacridine (Table 3, entry 7): Yield 90\%, m.p.: 270$272^{\circ} \mathrm{C},\left(270-272^{\circ} \mathrm{C}\right)^{27} ;{ }^{1} \mathrm{H}$ NMR $\left(400 \mathrm{MHz}, \mathrm{CDCl}_{3}\right) \delta$ (ppm): $8.82(\mathrm{~s}, 1 \mathrm{H}, \mathrm{NH}), 7.12(\mathrm{~d}, J=8.6 \mathrm{~Hz}, 2 \mathrm{H}, \mathrm{Ar}-\mathrm{H})$, $6.64(\mathrm{~d}, J=8.6 \mathrm{~Hz}, 2 \mathrm{H}, \mathrm{Ar}-\mathrm{H}), 4.83(\mathrm{~s}, 1 \mathrm{H}, \mathrm{CH}), 3.65(\mathrm{~s}$, $\left.3 \mathrm{H}, \mathrm{O}-\mathrm{CH}_{3}\right), 2.35(\mathrm{~d}, J=17.0 \mathrm{~Hz}, 2 \mathrm{H}), 2.24(\mathrm{~d}, J=16.3$ $\mathrm{Hz}, 2 \mathrm{H}), 2.10$ (d, $J=15.9 \mathrm{~Hz}, 2 \mathrm{H}), 1.98$ (d, $J=16.2 \mathrm{~Hz}$, 2H), $1.01\left(\mathrm{~s}, 6 \mathrm{H}, \mathrm{CH}_{3}\right), 0.98\left(\mathrm{~s}, 6 \mathrm{H}, \mathrm{CH}_{3}\right) ;{ }^{13} \mathrm{C} \mathrm{NMR}$ $\left(75 \mathrm{MHz}, \mathrm{CDCl}_{3}\right) \delta: 192.4,154.6,149.1,138.9,128.6$, $112.8,111.8,54.6,51.8,32.2,30.3,28.9,26.5$; IR ( $\mathrm{KBr}$, $\mathrm{cm}^{-1}$ ): 3448, 2954, 1643, 1612, 1365, 1141.
3,3,6,6-Tetramethyl-9-(4-methylphenyl)-1,8-dioxo-decahydroacridine (Table 3, entry 8): Yield 79\%, m.p.: 272$274^{\circ} \mathrm{C},\left(271-273^{\circ} \mathrm{C}\right)^{27}$; ${ }^{1} \mathrm{H}$ NMR $\left(400 \mathrm{MHz}, \mathrm{CDCl}_{3}\right) \delta$ (ppm): 11.9 (s, 1H, NH), 7.09 (d, $J=9 \mathrm{~Hz}, 2 \mathrm{H}, \mathrm{Ar}-\mathrm{H})$, $6.98(\mathrm{~d}, J=9 \mathrm{~Hz}, 2 \mathrm{H}, \mathrm{Ar}-\mathrm{H}), 5.50(\mathrm{~s}, 1 \mathrm{H}, \mathrm{CH}), 2.29$ (s, $\left.3 \mathrm{H}, \mathrm{CH}_{3}\right), 2.19-2.47\left(\mathrm{~m}, 8 \mathrm{H}, \mathrm{CH}_{2}\right), 1.22\left(\mathrm{~s}, 6 \mathrm{H}, \mathrm{CH}_{3}\right)$, $1.09\left(\mathrm{~s}, 6 \mathrm{H}, \mathrm{CH}_{3}\right) ;{ }^{13} \mathrm{C} \mathrm{NMR}\left(75 \mathrm{MHz}, \mathrm{CDCl}_{3}\right) \delta: 190.6$, $135.5,135.1,129.3,128.9,126.5,117.7,47.2,46.6,32.5$, 31.3, 29.8, 27.4; 20.9; IR (KBr, cm $\left.{ }^{-1}\right): 2958,2877,1569$, 1369.

\section{Conclusion}

In summary, here we report a simple and economically viable one-pot method for the synthesis of 1,8-dioxodecahydroacridine derivatives, via Hantzsch condensation of dimedone, $\mathrm{NH}_{4} \mathrm{OAc}$ with various aromatic aldehydes using commercially available, inexpensive citric acid as a greenorgano catalyst. Some important advantages of this 
RESEARCH ARTICLES

Table 3. Synthesis of 1,8-dioxo-decahydroacridine derivatives ${ }^{\mathrm{a}}$

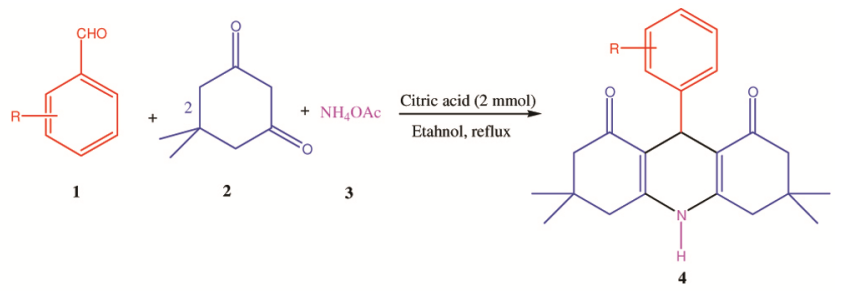

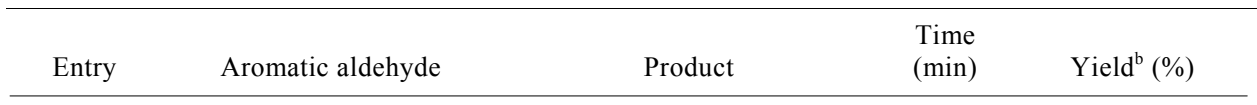

1

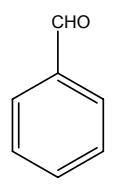

2

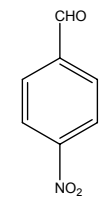

3<smiles>O=Cc1ccc(Cl)cc1</smiles>

4<smiles>O=Cc1ccc(Br)cc1</smiles>

5<smiles>N#Cc1ccc(C=O)cc1</smiles>

6<smiles>O=Cc1ccc(O)cc1</smiles>

7<smiles>COc1ccc(C=O)cc1</smiles>

150

89

100

90

160

87

180

85

200

74

160

83

210

90

(Contd)

940

CURRENT SCIENCE, VOL. 116, NO. 6, 25 MARCH 2019 
RESEARCH ARTICLES

Table 3. (Contd)

\begin{tabular}{|c|c|c|c|c|}
\hline Entry & Aromatic aldehyde & Product & $\begin{array}{l}\text { Time } \\
\text { (min) }\end{array}$ & Yield $^{\mathrm{b}}(\%)$ \\
\hline 8 & & & 130 & 79 \\
\hline 9 & & & 230 & 80 \\
\hline 10 & & & 240 & 81 \\
\hline 11 & & & 300 & 45 \\
\hline
\end{tabular}

${ }^{a}$ Reaction conditions: Dimedone $(2 \mathrm{mmol})$, aryl aldehyde $(1 \mathrm{mmol}), \mathrm{NH}_{4} \mathrm{OAc}(1.5 \mathrm{mmol})$ and citric acid monohydrate $(2 \mathrm{mmol})$ in ethanol $(4 \mathrm{ml})$ at reflux. ${ }^{\mathrm{b}}$ Isolated yields.

Table 4. Effect of various catalysts on the synthesis of 1,8-dioxo-decahydroacridines

\begin{tabular}{lllrcc}
\hline Entry & \multicolumn{1}{c}{ Catalyst } & Reaction condition & $\begin{array}{c}\text { Time } \\
(\mathrm{min})\end{array}$ & $\begin{array}{c}\text { Yield } \\
(\%)\end{array}$ & Reference \\
\hline 1 & Citric acid $(2 \mathrm{mmol})$ & Ethanol/reflux & 150 & 89 & Present study \\
2 & $\mathrm{Ni}_{0.5} \mathrm{Co}_{0.5} \mathrm{Fe}_{2} \mathrm{O}_{4}(20 \mathrm{~mol} \%)$ & EtOH $: \mathrm{H}_{2} \mathrm{O}(1: 1)$, reflux & 40 & 92 & 24 \\
3 & $\mathrm{SiO}_{2}-\mathrm{ZnCl}_{2}(0.2 \mathrm{~g} \mathrm{~mol} \%)$ & Solvent-free $/ 100^{\circ} \mathrm{C}$ & 30 & 70 & 20 \\
4 & $\mathrm{~B}\left(\mathrm{C}_{6} \mathrm{~F}_{5}\right)_{3}(3 \mathrm{~mol} \%)$ & Solvent-free $/ \mathrm{RT}$ & 168 & 80 & 29 \\
5 & $\mathrm{PPA}-\mathrm{SiO}_{2}(0.02 \mathrm{~g})$ & Solvent-free $/ 100^{\circ} \mathrm{C}$ & 10 & 93 & 30 \\
6 & $\mathrm{Ammonium}$ chloride & Solvent-free $/ 120^{\circ} \mathrm{C}$ & 60 & 87 & 31 \\
7 & $\mathrm{SPNP}(0.03 \mathrm{mmol})$ & $\mathrm{H}_{2} \mathrm{O}$, reflux & 120 & 91 & 32 \\
\hline
\end{tabular}

method are the use of inexpensive reagents, absence of toxic effluents, use of green solvent and easy work-up procedure. In addition, the catalyst could be reused for at least three runs with a modest change in the product yield.

1. Liu, P., Hao, J. W., Mo, L. P. and Zhang, Z. H., Recent advances in the application of deep eutectic solvents as sustainable media as well as catalysts in organic reactions. $R S C A d v$., 2015, 5, 4867548704.

2. Vladu, M. I., 'Green' electronics: biodegradable and biocompatible materials and devices for sustainable future. Chem. Soc. Rev., 2014, 43, 588-610.

3. Khedkar, S. A. and Auti, P. B., 1, 4-Dihydropyridines: a class of pharmacologically important molecules. Mini. Rev. Med. Chem., 2014, 14, 282-290.
4. Huang, C., Yan, S. J., Li, Y. M., Huang, R. and Lin, J., Synthesis of polyhalo acridones as $\mathrm{pH}$-sensitive fluorescence probes. Bioorg. Med. Chem. Lett., 2010, 20, 4665-4669.

5. Anandan, S., Madhavan, J., Maruthamuthu, P., Raghukumar, V. and Ramakrishnan, V. T., Synthesis and characterization of naphthyridine and acridinedione ligands coordinated ruthenium (II) complexes and their applications in dye-sensitized solar cells. Sol. Energy Mater. Sol. Cells, 2004, 81, 419-428.

6. Islam, A., Murugan, P., Hwang, K. C. and Cheng, C. H., Blue light-emitting devices based on 1,8-acridinedione derivatives. Synth. Met., 2003, 139, 347-353.

7. Rajendran, A. and Nair, B. U., Unprecedented dual binding behaviour of acridine group of dye: a combined experimental and theoretical investigation for the development of anticancer chemotherapeutic agents. Biochim. Biophys. Acta. Gen.-Subjects, 2006, 1760, 1794-1801. 


\section{RESEARCH ARTICLES}

8. Alvala, M., Bhatnagar, S., Ravi, A., Jeankumar, V. U., Manjashetty, T. H., Yogeeswari, P. and Sriram, D., Novel acridinedione derivatives: design, synthesis, SIRT1 enzyme and tumor cell growth inhibition studies. Bioorg. Med. Chem. Lett., 2012, 22, 32563260 .

9. Cholody, W. M., Horowska, B., Paradziej-Lukowicz, J., Martelli, S. and Konopa, J., Structure-activity relationship for antineoplastic imidazoacridinones: synthesis and antileukemic activity in vivo. J. Med. Chem., 1996, 39, 1028-1032.

10. Mikata, Y., Yokoyama, M., Mogami, K., Kato, M., Okura, I., Chikira, M. and Yano, S., Intercalator-linked cisplatin: synthesis and antitumor activity of cis-dichloroplatinum(II) complexes connected to acridine and phenylquinolines by one methylene chain. Inorg. Chem. Acta, 1998, 279, 51-57.

11. Lacasagne, A., Buu-Ho, N. P., Daudel, R. and Zajdela, F., The relation between carcinogenic activity and the physical and chemical properties of angular benzacridines. Adv. Cancer Res., 1956, 4, 315-369.

12. Berkan, O., Sarac, B., Simsek, R., Yildirim, S., Sariogli, Y. and Safak, C., Vasorelaxing properties of some phenylacridine type potassium channel openers in isolated rabbit thoracic arteries. Eur. J. Med., 2002, 37, 519-523.

13. Wainwright, M. J. J., Acridine - a neglected antibacterial chromophore. Antimicrob. Chemother., 2001, 47, 1-13.

14. Suarez, M., Loupy, A., Salfran, E., Moran, L. and Rolando, E., Synthesis of decahydroacridines under microwaves using ammonium acetate supported on alumina. Heterocycles, 1999, 51, $21-$ 27.

15. Bakibaev, A. A., Fillimonov, V. D. and Nevgodova, E. S., Ureas in the organic synthesis. Part 6. Reactions of 1,3-dicarbonyls with azomethines and urea in DMSO as a method for the synthesis of arylacridines. Zh. Org. Khim., 1991, 27, 1512-1519.

16. Martin, N. et al., Synthesis and conformational study of acridine derivatives related to 1,4-dihydropyridines. J. Heterocyclic Chem., 1995, 32, 235-238.

17. Tu, S. J., Lu, Z., Shi, D., Yao, C., Gao, Y. and Guo, C., A convenient synthesis of 9-aryl-3,3,6,6-tetramethyl-1,2,3,4,5,6,7,8,9,10decahydroacridine-1,8-diones under microwave irradiation without solvent. Synth. Commun., 2002, 32, 2181-2185.

18. Tu, S., Fang, F., Zhu, S., Li, T., Zhang, X. and Zhuang, Q., Onepot synthesis of a novel compound $N$-hydroxydecahydroacridine under microwave irradiation. J. Heterocyclic Chem., 2004, 41, $767-770$.

19. Vekariya, R. H. and Patel, H. D., Sulfonated polyethylene glycol $\left(\mathrm{PEG}-\mathrm{OSO}_{3} \mathrm{H}\right)$ as a polymer supported biodegradable and recyclable catalyst in green organic synthesis: recent advances. RSC $A d v$., 2015, 5, 49006-49030.

20. Soliman, H. A., Mubarak, A. Y., EL-Mekabati, A. and Elmorsy, S. $\mathrm{S}$., $\mathrm{SiO}_{2} / \mathrm{ZnCl}_{2}$-catalyzed heterocyclic synthesis: green, rapid and efficient one-pot synthesis of 14- $H$-dibenzo[ $a, j]$ xanthenes, 1,8dioxo-octahydroxanthenes and 1,8-dioxo-decahydroacridines under solvent-free conditions Chem. Sci. Trans., 2014, 3, 819825 .

21. Khalafi-Nezhad, A., Panahi, F., Mohammadi, S. and Foroughi, H. O., A green and efficient procedure for one-pot synthesis of xanthenes and acridines using silica boron-sulfuric acid nanoparticles (SBSANs) as a solid lewis-protic acid. J. Iran. Chem. Soc., 2013, 10, 189-200.

22. Venkatesan, K., Pujari, S. S. and Srinivasan, K. V., Proline-catalyzed simple and efficient synthesis of 1,8-dioxo-decahydroacridines in aqueous ethanol medium. Synth. Commun., 2009, 1, 228-241.

23. Saeed, B., Fatemeh, C., Fatemeh, D. and Hamid Reza, B., One-pot synthesis of 1,8-dioxo-decahydroacridine derivatives in aqueous media. Chin. J. Chem., 2009, 27, 1953-1956.
24. Maripi, S., Korupolu, R. B. and Madasu, S. B., Nano nickelcobalt ferrite catalysed one-pot multi-component synthesis of xanthenediones and acridinediones. Green Sustain. Chem., 2017, 7, 70-84.

25. Davoodnia, A., Khojastehnezhad, A. and Tavakoli-Hoseini, N., Carbon-based solid acid as an efficient and reusable catalyst for the synthesis of 1,8-dioxodecahydroacridines under solvent-free conditions. Bull. Korean Chem. Soc., 2011, 32, 2243-2248.

26. Shen, W., Wang, L. M., Tian, H., Tang, J. and Yu, J. J., Brønsted acidic imidazolium salts containing perfluoroalkyl tails catalyzed one-pot synthesis of 1,8-dioxo-decahydroacridines in water. J. Fluorine Chem., 2009, 130, 522-527.

27. Sehout, I., Boulcina, R., Boumoud, B., Boumoud, T. and Debache, A., Solvent-free synthesis of polyhydroquinoline and 1,8-dioxodecahydroacridine derivatives through the Hantzsch reaction catalyzed by a natural organic acid: a green method. Synth. Commun., 2017, 47, 1185-1191.

28. Gomez, S. M. M., Alzate-Sanchez, D. M., Rodriguez-Cordoba, W., Sierra, C. A. and Ochoa-Puentes, C., Competitive one-pot reactions: simultaneous synthesis of decahydroacridine-1,8-diones and 1,8-dioxo-octahydroxanthenes and photophysical characterization. Synth. Commun., 2014, 44, 648-659.

29. Chandrasekhar, S., Rao, Y. S., Sreelakshmi, L., Mahipal, B. and Reddy, C. R., Tris(pentafluorophenyl)borane-catalyzed threecomponent reaction for the synthesis of 1,8-dioxodecahydroacridines under solvent-free conditions. Synthesis, 2008, 11, 1737-1740.

30. Moeinpour, F. and Khojastehnezhad, A., An efficient one-pot synthesis of 1,8-dioxodecahydroacridines using silica-supported polyphosphoric acid $\left(\mathrm{PPA}-\mathrm{SiO}_{2}\right)$ under solvent-free conditions. E-J. Chem., 2012, 9, 504-509.

31. Banerjee, B. and Brahmachari, G., Ammonium chloride catalysed one-pot multicomponent synthesis of 1,8-dioxo-octahydroxanthenes and $N$-aryl-1,8-dioxodecahydroacridines under solvent free conditions. J. Chem. Res., 2014, 38, 745-764.

32. Javid, A., Khojastehnezhad, A., Heravi, M. and Bamoharram, F. F., Silica-supported Preyssler nanoparticles catalyzed simple and efficient one-pot synthesis of 1,8-dioxodecahydroacridines in aqueous media. Synth. React. Inorg. Met. Org. Chem., 2012, 42, 14-17.

33. Karhale, S., Patil, K., Bhenki, C., Rashinkar, G. and Helavi, V., Zirconocene catalyzed synthesis of 2-substituted benzimidazole derivatives. Res. Chem. Intermed., 2016, 42, 7257-7268.

34. Karhale, S., Survase, D., Bhat, R., Ubale, P. and Helavi, V., A practical and green protocol for the synthesis of 2,3-dihydroquinazolin-4(1H)-ones using oxalic acid as organocatalyst. Res. Chem. Intermed., 2017, 43, 3915-3924.

35. Karhale, S., Patil, M., Rashinkar, G. and Helavi, V., Green and cost effective protocol for the synthesis of 1,8-dioxo-octahydroxanthenes and 1,8-dioxo-decahydroacridines by using sawdust sulphonic acid. Res. Chem. Intermed., 2017, 43, 7073-7086.

36. Karhale, S., Bhenki, C., Rashinkar, G. and Helavi, V., Covalently anchored sulfamic acid on cellulose as heterogeneous solid acid catalyst for the synthesis of structurally symmetrical and unsymmetrical 1,4-dihydropyridine derivatives. New J. Chem., 2017, 41, 5133-5141.

37. Patil, M. A., Ubale, P. A., Karhale, S. S. and Helavi, V. B., Lemon juice: an environmentally benign catalyst for synthesis of benzothiazoles and benzoxazole derivatives in aqueous medium. Chem. Sin., 2017, 8, 198-205.

Received 3 February 2018; revised accepted 16 April 2018

doi: $10.18520 / \mathrm{cs} / \mathrm{v} 116 / \mathrm{i} 6 / 936-942$ 